Financial Markets, Institutions and Risks, Volume 3, Issue 4, 2019

ISSN (online) - 2521-1242 ISSN (print) - 2521-1250

\title{
Implications of Financial Intermediation on The Performance of Commercial Banks in Nigeria: 2000-2017
}

\author{
Adewole Joseph Adeyinka, ORCID: http://orcid.org/0000-0002-0676-5480 \\ $\mathrm{PhD}$, Department of Banking and Finance, Faculty of Social and Management Sciences, Adekunle Ajasin \\ University, P.M.B 001, Akungba Akoko, Ondo State, Nigeria
}

Dare Funso David, ORCID: http://orcid.org/0000-0003-4232-1817

$\mathrm{PhD}$, Department of Banking and Finance, Faculty of Social and Management Sciences, Adekunle Ajasin University, P.M.B 001, Akungba Akoko, Ondo State, Nigeria

Ogunyemi Joseph Kayode, ORCID: http://orcid.org/0000-0002-1449-2937

Department of Banking and Finance, Faculty of Social and Management Sciences, Adekunle Ajasin University, P.M.B 001, Akungba Akoko, Ondo State, Nigeria

\begin{abstract}
The paper examined the arguments and counterarguments within the scientific discussion on Financial Intermediation and the performance of Commercial banks in Nigeria. Despite a series of reforms and restructuring aimed at enhancing the bank's ability to provide services effectively, establish branch networks and finance the real sector, there is still insufficient domestic credit to commercial real-estate banks, affecting the success of financial intermediation in the Nigerian commercial banking sector. The main purpose of this study is to examine the impact of financial intermediation on the performance of commercial banks in Nigeria. The data came from a statistical bulletin of the Central Bank of Nigeria. A systematic literary approach to data analysis is regression analysis. In Equation 1, it was found that there is a significant relationship between total lending and the commercial bank lending rate in Nigeria. In Equation 2, it was found that there is a significant relationship between the overall credit ratio and the cash reserve in the commercial banks of Nigeria. In the commercial bank performance equation, it was found that there is a significant relationship between the total assets and the capital involved by commercial banks in Nigeria. In the commercial bank performance equation, it was found that there was no significant relationship between the loan and deposit ratio and the liquidity ratio in the commercial banks of Nigeria. It has also been found in Commercial Banking Performance Equation 5 that there is a significant relationship between gross domestic product and total credit in the commercial banks of Nigeria. Thus, the study authors recommend reducing the commercial bank loan rate so that investors see commercial banks as the number one source of funding, the Central Bank of Nigeria should increase the commercial banks' minimum reserve in order to facilitate adequate lending to commercial customers by clients/investors. Commercial banks need to make effective use of the capital used to increase profitability. Commercial banks should help increase liquidity to increase their ability to cover customer withdrawals and increase loans and advances to customers. Commercial banks should allocate proper credit to the real sector for productive purposes in order to increase gross domestic product.
\end{abstract}

Keywords: Financial Intermediation, Commercial Banks, Gross Domestic Product, Commercial Bank Credit. JEL Classification: G21, G28, G29.

Cite as: Adewole, J.A, Dare, F.D., Ogunyemi, J.K. (2019). Implications of Financial Intermediation on The Performance of Commercial Banks in Nigeria: 2000-2017. Financial Markets, Institutions and Risks, 3(4), 94105. http://doi.org/ 10.21272/fmir.3(4). 94-105.2019

(C) The Authors, 2019. This article is published with open access at Sumy State University.

\section{Introduction}

Financial Intermediation is the process of mobilizing funds from the surplus economic unit to the deficit economic unit. In other words, financial intermediation is the process of mobilizing financial resources from the ultimate saver to the ultimate user. Andrew and Osuji (2013), state that financial intermediation involves the transformation of mobilized deposits liabilities by banks into banks assets or credits such as loans and overdraft. This means that financial intermediation is the process of taking in money from depositors and lending same to borrowers for investments which in turn help the economy to grow. According to Blum (2002), 
Financial Markets, Institutions and Risks, Volume 3, Issue 4, 2019 ISSN (online) - 2521-1242 ISSN (print) - 2521-1250

financial intermediation is the process of transferring the savings of some economic units to others for consumption or investment at a price.

Onodugo, Anowor and Kalu (2013) opined that financial intermediation play a very vital role in economic development in Nigeria. For financial intermediation to aid development, there must be an efficient financial system. This means that financial intermediation mitigates the costs associated with information acquisition and the conduct of financial transactions through the level of lending rate and credit to private sector in accelerating development in an economy.

In financial intermediation, there is direct and indirect finance. Direct finance is a form of financial intermediation that does not require the activities of middlemen i.e it does not require the activities of financial intermediaries; the lender makes credit available to the borrower directly. Indirect finance is a form of financial intermediation that require the activities of middlemen i.e this method makes use of financial intermediaries when mobilizing fund from the surplus economic unit to the deficit economic unit. Financial Intermediation role is being played by financial sector of the economy which can be formal or informal. Formal financial sector is a financial sector that operates under a regulatory bodies like Central Bank of Nigeria (CBN), Nigeria deposit insurance corporation (NDIC), Security and exchange commission (SEC) e.t.c. Informal financial sector is a kind of financial sector that do not operate under a regulatory body like thrift (Ajo Esusu in Yoruba Language, Adasi in Hausa Language), Local Money Lenders, Cooperative Societies.

The real sector of the economy forms the main driving force of the economy. It is the engine of economic growth and development. Largely, the real sector depends on the banking sector for the provision of the required funds for investment purposes. Thus, it means that an increase in the bank lending to the real sector will increase the activities of the real sector and vice versa (Blum, 2002). Based on the assumption that the banking sector plays an important role in financing the real sector, Central Bank of Nigeria have carried out reforms and institutional innovations in the commercial banking with the aim of ensuring financial stability so as to influence the growth of the economy and also to ensure that commercial banks plays the critical roles of financial intermediation in Nigeria.

Despite the series of reforms and restructuring aimed at strengthening the bank ability to efficient service delivery, branch networking and fund the real sector, inadequate domestic credit by the commercial banks to the real sector still persist. As reported by Adeoye (2003), the Commercial banking services are still inadequate and unattractive to borrowers because they do not favour long-term lending, and even for short-term lending, their high interest rates do not only discourage borrowing but also make repayment difficult. Moreover, the effect of policy distortions on the ability of Commercial banks to supply credit to the various sectors is reflected in their dismal performance. The broad objective of this study is to examine the effect of financial intermediation on the performance of Commercial Banks in Nigeria within the period of $2000-2017$. The specific objectives are to examine the relationship between Total Bank Credit and Lending rate of Commercial Banks in Nigeria, to find out the relationship between Total Bank Credit and Current Reserve Ratio of Commercial Banks in Nigeria, to determine the relationship between Total asset and Capital employed by Commercial Banks in Nigeria, to examine the relationship between Loans to deposit ratio and Liquidity ratio of Commercial Banks in Nigeria and to investigate the relationship between Gross Domestic Product and Total Credit of Commercial Banks in Nigeria.

The hypotheses of this study are presented in a null form which states that there is no significant relationship between Total Bank Credit and Lending rate of Commercial Banks in Nigeria, there is no significant relationship between Total Bank Credit and Current Reserve Ratio of Commercial Banks in Nigeria, there is no significant relationship between Total asset and Capital employed by of Commercial Banks in Nigeria, there is no significant relationship between Loans to deposit ratio and Liquidity ratio of Commercial Banks in Nigeria, there is no significant relationship between Gross Domestic Product and Total Bank Credit of Commercial Banks in Nigeria.

This research provides an in-depth analysis, which would enable the Nigerian populace to fully understand the nitty-gritty of the performance of Commercial Bank in Nigeria and ultimately enable them to be very much familiar with Commercial Bank Financial Intermediation role. This study is important at this level of economic development when efforts are being made to reposition the financial system to enable it play key roles in economic development of Nigeria. The study essentially seeks to examine in an empirical manner, the nature of Commercial Bank in Nigeria since 2000 up to 2017. The study shall seek to ascertain the critical factors that have affected the level of financial intermediation of Commercial Banks in Nigeria. This study is justifiable since it will employ the crucial methodology analysis used in examining the flows of credit in the 
Financial Markets, Institutions and Risks, Volume 3, Issue 4, 2019

ISSN (online) - 2521-1242 ISSN (print) - 2521-1250

commercial banking system. While most studies conducted on commercial bank and financial intermediation examined the banks activities up to 2014 (Tonye and Andabai, 2014). The periods covered also made the study unique to others. It covered eighteen years ranging from 2000 to 2017. Although, the performance of commercial banks has been well documented in both international and domestic literature, this work seeks to add to the research by examining the relationship between financial intermediation in commercial banks and its performance which is a quiet departure from previous studies that focused on the determinant of commercial bank credit to small and medium scale enterprise.

This study will be a critical comparative analysis of the implications of financial intermediation on the performance of commercial banks in Nigeria for the periods 2000 to 2017. The study chooses this period in order to account for the structural changes in both demand and supply of credits in the commercial banking industry in Nigeria during pre and post consolidation era. The study covers all the commercial banks in Nigeria, it covers the concept and nature of financial intermediation, the flow of funds in direct and indirect finance, objectives, functions and benefits of financial intermediaries, types of financial intermediaries, financial intermediaries and asymmetric information, potential problems of financial intermediaries, benefits of financial intermediaries to lenders and borrowers, role of financial intermediaries in economic development, commercial banking reforms in Nigeria, challenges to commercial banking reforms in Nigeria, bank recapitalization and intermediation roles, developments in the Nigerian commercial banking sector, empirical review, theory of financial intermediation, supply leading theory, the financial liberalization theory, the quantity theory of credit, information asymmetry theory, theory of economic growth, critique of the theoretical framework, critique of gaps in the literature.

\section{Literature Review}

\section{Concept and Nature of Financial Intermediation}

To ensure that investible funds are made available for economic activities, social and community services sector inclusive in the urban and rural areas and the quest for overall development of the economy informed the decision of financial system focusing more on financial intermediation. Financial intermediation is typically an institution that facilitates the channeling of funds between lenders and borrowers indirectly. That is, savers (lenders) give funds to an intermediary institution (such as a bank), and that institution gives those funds to spenders (borrowers). Gorton \& Winton (2002) define financial intermediaries as firms that borrow consumers/savers and lend same to companies that need resources for investment.

Financial intermediaries can be classified into institutional investors, pure intermediaries like investment banks and Deposit Money Banks. Among all the financial intermediaries, banks are the major financial intermediaries that accept deposits and make loans directly to the borrowers (Quilym, 2012).

Mahmood and Bilal (2010), opined that the rising magnitude of financial intermediation have adverse implications on the growth of Nigerian economy because in the absence of developed capital market, the private sector which contributes a greater percentage to economic growth in Nigeria will primarily depend on bank credit as a source of financing their investments which will lead to economic growth. This means that the constant rise of financial intermediation discourages potential savings due to low returns on deposits, and ultimately reduces lending activities and investment potential of investors as a result of high cost of funding (Ndung'u \& Ngugi, 2000; Mahmood \& Bilal, 2010). Financial intermediation involves the transformation of mobilized deposits liabilities by financial intermediaries such as banks into bank assets or credits such as loan and overdraft. It is simply the process whereby financial intermediaries take in money from depositors and lend same out to borrowers for investment and other economic development purposes (Andrew \& Osuji, 2013). According to Acha (2011), financial intermediation is a system of channeling funds from lenders (economic surplus unit) to borrowers (economic deficit unit) through financial institutions. Financial markets link savers and borrowers. The link is accomplished through either direct finance or indirect finance.

Direct Finance occurs when savers lend funds directly to borrowers. For instance, if a student asks a classmate to loan him/her money to buy a new car and he/she agrees, you are engaging in direct finance. There is no third party involved that brought the two persons; in fact, most indirect finance often involves the assistance of a third party, such as a broker, who brings buyer and seller together. When International Business Machine (IBM) issued new bonds, it uses the service of various specialists in the financial markets. So, also was Dangote group of Businesses either for its cement or sugar etc. For now, simply note that the ultimate buyers of Dangote 
Financial Markets, Institutions and Risks, Volume 3, Issue 4, 2019 ISSN (online) - 2521-1242 ISSN (print) - 2521-1250

cement or IBM bonds of shares will usually engage the services of a broker to arrange the sales. This is oneway financial markets facilitates direct finance.

An indirect finance which is in contrast involves a particular type of middleman-a third party who stands between the borrower and the lender. This middleman is called a financial intermediary and his or her role is to accumulate funds from various savers and loan those funds to borrowers . Banks are financial intermediaries because they accept deposits and lend the funds to borrowers. This is illustrated in the flow of funds in direct and indirect finance below:

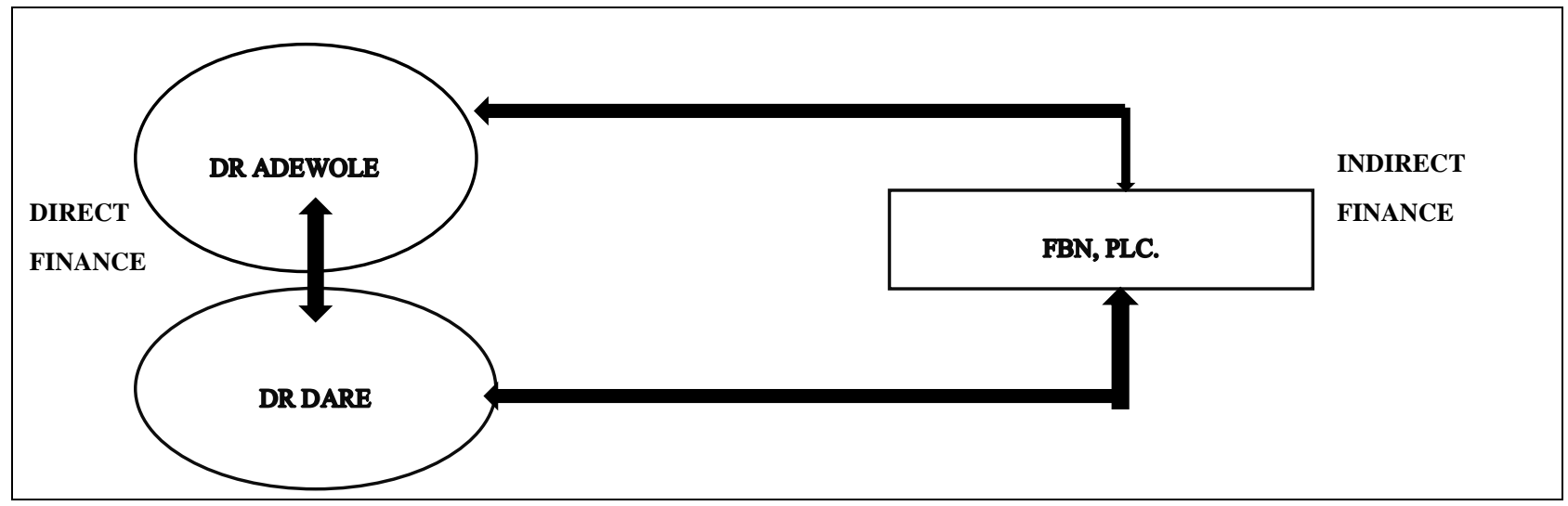

Figure 2.1. Diagram of the flow of funds in direct and indirect finance

Source: Authors Diagram, 2019.

In the diagram above, it indicates the flow of funds between lender and borrowers under direct and indirect finance. With the direct finance, the lender (DR ADEWOLE who provided funds directly to borrower, DR DARE). In this case, there is no middleman involved, but with the indirect finance, DR ADEWOLE deposits his money in a financial intermediary such as FBN, Plc. which will in turn give out the money as loan to DR DARE. Note that in this case, the financial intermediary is both a borrower and also a lender.

Why can't depositors skip intermediary and engage in direct finance. After all, since banks charges a higher rate on loans than it pays to its depositors, it would seem that a depositor could do better by making a direct loan to a borrower or a borrower could get a lower rate by borrowing directly from a saver. The answer to this question lies in the role the intermediaries play in an economy (country). Note also that we could ask why consumers don't buy goods directly from factories instead of from retailers. The answer is that the benefits derived from using intermediaries exceed the external cost of dealing with them.

\section{Role of Financial Intermediaries in Economic Development}

Banks directly play an important role in the economic development of the country. Here, we can see certain specific role of banks as financial intermediary.

1. Self-employment programme: Employment growth is a sign of economic development. Financial Intermediaries, by providing finance for starting self-employment programmes are generating more production and income in the country. In India, after the nationalization of commercial banks, a number of programmes have been initiated by banks for self-employment schemes.

2. Entrepreneurial Development Programmes (EDPs): have been successfully launched by various banks. Initially through Lead Bank Scheme, banks were developing employment opportunities at the district level. Later on, Service Area Approach was adopted in 1978 by which certain specific areas were allotted to the banks for launching different economic programmes for the development of such areas.

3. Integrated Rural development scheme: Under this scheme, financial intermediaries were financing socially and economically depressed people by providing loans to them for various economic activities. One third of the loan will be a subsidy and the remaining two-thirds of the loan will carry a lower rate of interest under the interest subsidy scheme of RBI. In this way, various economic programmes aimed at improving rural economic conditions were undertaken.

4. Housing Finance: As a part of improving dwelling houses, financial intermediaries are providing housing loans. They are also providing refinancing facility to agencies such as HUDCO (Housing and Urban Development Corporation). This has enabled many fixed income group people to avail the housing loan. 
Financial Markets, Institutions and Risks, Volume 3, Issue 4, 2019

ISSN (online) - 2521-1242 ISSN (print) - 2521-1250

Normally, to a borrower under this facility, a bank provides 3-year aggregate net income as a maximum amount or the cost of the house, whichever is less.

5. Priority Sector: As per RBI guidelines, commercial banks have to provide certain percentage of their lending to priority sector which consists of agriculture and its allied activities, such as poultry, dairy, etc, cottage industries, small scale industries, small industry and business.

6. Backward area Development: In order to prevent regional disparities, financial intermediaries have been advancing loans to industries which are started in backward areas. Government has given certain concessions in the form of tax benefits to such industries and banks provide cheap loans so that the backward areas could attract more industries.

7. Introduction of Electronic system: Computer is being used by financial intermediaries for most of their activities now and they are able to link their branches through a network. This has resulted in quicker transfer of funds between centres and this has helped customers in realizing their cheques in a speedy manner. It is for this purpose, that Magnetic Ink Character Recognition (MICR) cheques have been introduced. The customer can also make use of Home banking facility by linking their computer system with the bank and instructions can be provided for transfer of funds. This facility, if developed throughout the country, will not only help in the movement of funds but also reduce the disparity in the interest rate.

\section{Methods}

The research design adopted in this study is ex-post facto. Time Series Annual data on commercial banks financial intermediation performance were extracted from statistical bulletin of central bank of Nigeria for the period 2000 - 2017. This method is considered appropriate because it will be used to establish whether, and to what degree of impact that exist between two or more quantifiable variables (Oneme, 2010). Research design provides the framework for finding solution to any problem under study. In this line, Osuala (2010) is of the opinion that the choice of research design is determined by the focused objectives of the study. In addition, the result from the test of hypotheses can be used to generalize the findings of the study. However, this chapter presents the Sources of data, Method of data analysis, Description of Research Variables, Model specification, Estimation Techniques. It also contains a detailed outline of systems of modelling equations that was be used to achieve the objectives of this study. However, this work focuses on the implications of financial intermediation on the performance of commercial bank in Nigeria.

This study relied basically on secondary data which was obtained from Central Bank of Nigeria statistical bulletin from 2000 to 2017 . Thus, the study took a complete census of pre consolidated commercial banks from the year 2000 and post consolidated commercial banks in Nigeria. This is considered sufficient to produce robust and generalizable results. Yearly data was extracted from the income statements and balance sheets of commercial banks.

In this study, the type of data analysis that was employed is the inferential statistics (i.e parametric statistics), such as simple and multiple regression analyses. Statistical Package for Social Sciences (SPSS) version 16.0 was used to present the results. Several authors have also used this approach in their works (Reinhart \& Tokatlidis, 2000; Adam, 2007). To achieve the stated objectives, five equations were used to capture the stated objectives. These are the credit supply equation 1 , credit supply equation 2 , commercial bank performance equation 3, commercial bank performance equation 4, and commercial bank performance equation 5 . The credit supply equation 1 was used to assess the credit flows of commercial banks in Nigeria, Credit supply equation 2 was used to determine the credit flows of commercial banks in Nigeria, Commercial bank performance equation 3 was used to assess the asset performance of commercial banks in Nigeria, Commercial bank performance equation 4 was used to compare the ratio of commercial banks deposit to its loans, Commercial bank performance equation 5 was used to know the contributions of bank financial intermediation to gross domestic product.

Bank Total credit is the amount of credit available to a company or individual from the banking system. It is the aggregate of the amount of funds financial institutions are willing to provide to an individual or organization. Gross domestic product (GDP) is the monetary value of all the finished goods and services produced within a country's borders in a specific time period. Though GDP is usually calculated on an annual basis, it can be calculated on a quarterly basis as well. Total Asset is the final amount of all gross investments, cash and equivalents, receivables, and other asset as are presented on the balance sheet. The loan-to-deposit 
ratio is used to assess a bank's liquidity by comparing a bank's total loans to its total deposits for the same period. This number is expressed as a percentage. If the ratio is too high, it means that the bank may not have enough liquidity to cover any unforeseen fund requirements. Conversely, if the ratio is too low, the bank may not be earning as much as it could be. Liquidity ratio is the class of financial metrics used to determine a company's ability to pay off its short-terms debts obligations. Generally, the higher the value of the ratio, the larger the margin of safety that the company possesses to cover short-term debts. Lending rate (interest rate) is the bank rate that usually meets the short and medium medium-term loan financing needs of the private sector. This rate is normally differentiated according to creditworthiness of borrowers and objectives of financing. Cash reserve ratio is a specified minimum fraction of the total deposits of customers, which commercial banks have to hold as reserve either in cash or as deposits with the central bank. CRR is set according to the guidelines of the central bank of a country. Capital Employed is also known as funds employed, is the total amount of capital used for the acquisition of profits. It is the value of all the assets employed in a business. Total deposit and Shareholders fund are example of capital employed in the banking industry. Total Deposit consists of money placed into banking institutions for safekeeping. These deposits are made to deposit accounts such as savings accounts, current accounts and time deposit accounts. The deposit itself is a liability owed by the bank to the depositor. Bank deposits refer to this liability rather than to the actual funds that have been deposited. Shareholders Fund refers to the amount of equity in a company, which belongs to the shareholders. Shareholders' fund is the balance sheet value of the shareholders' interest in a company. Shareholders' equity represents the interest of a company's shareholders in the net assets of the company. It equals the excess of a company's total assets over its total liabilities. A company's total assets are either brought in by the shareholders or financed by the creditors. Total credit was also used as independent variable in equation 5 in order to determine the contributions of commercial bank credit/loan to monetary value of all the finished goods and services produced within Nigerian economy.

To achieve the objectives of this study, the model concentrates on credit supply equation 1, credit supply equation 2, commercial bank performance equation 3, commercial bank performance equation 4, and commercial bank performance equation 5. These models are stated below:

\section{Credit Supply Equation}

$T C_{s i}=\alpha_{o}+\alpha_{1} L R A_{s i}+\mathrm{e} 1$

Where:

$T C=$ Total Bank credit; $\left(T C_{s i}\right)$

$\mathrm{X}_{1}=$ Lending Rate; $(L R A)$

$\alpha_{0}=$ Constant $(A)$;

$\alpha_{i}=$ Regression Coefficients;

$\mathrm{e}_{i}=$ Error term

\section{Credit Supply Equation}

$T C_{s i}=\alpha_{o}+\alpha_{l} C R R_{s i}+\mathrm{e}_{l} l$

Where:

$T C=$ Total Bank credit; $\left(T C_{s i}\right)$

$X_{1}=$ Cash Reserve Ratio; $(C R R)$

$\alpha_{0}=$ Constant (A);

$\alpha_{i}=$ Regression Coefficients;

$\mathrm{e}_{i}=$ Error term

\section{Commercial Bank performance equation}

$T A S_{s i}=\alpha_{o}+\alpha_{l} T D_{s i}+\alpha_{2} S H F+\mathrm{e}_{l}$

Where:

$Y_{i}=$ Total Asset $;(T A S)$

$x_{1}=$ Total deposit; $\left(T D_{s i}\right)$

$x_{2}=$ Shareholders Fund; $(S H F)$

$\alpha_{0}=$ Constant $(A)$;

$\alpha_{i}=$ Regression Coefficients;

$\mathrm{e}_{i}=$ Error term 


\section{Commercial Bank performance equation}

$L D R_{s i}=\alpha_{o}+\alpha_{1} L R_{s i}+\mathrm{e}_{1}$

Where:

$Y_{i}=$ Loans to deposit ratio; $(L D R)$

$x_{l}=$ Liquidity; $\left(L R_{s i}\right)$

$\alpha_{0}=$ Constant $(\mathrm{A})$;

$\alpha_{i}=$ Regression Coefficients;

$\mathrm{e}_{\mathrm{i}}=$ Error term

\section{Commercial Bank performance equation}

$\mathrm{GDP}_{\mathrm{si}}=\alpha_{0}+\alpha_{1} \mathrm{TC}_{\mathrm{si}}+\mathrm{e}_{1}$

Where

$Y_{i}=$ Gross Domestic Product; $(G D P)$

$x_{l}=$ Total Bank Credit; $\left(T D_{s i}\right)$

$\alpha_{0}=$ Constant $(A)$;

$\alpha_{i}=$ Regression Coefficients;

$\mathrm{e}_{i}=$ Error term

The models used annual data spanning through the period 2000-2017.

\section{Results}

\subsection{Data presentation}

Table 4.1. Total Asset, Shareholders Fund, Total Credit, Loan to deposit ratio, Liquidity Ratio, Total Deposit, Lending Rate, Cash Reserve Ratio, Gross Domestic Product of Commercial Banks

\begin{tabular}{|c|c|c|c|c|c|c|c|c|c|}
\hline Years & $\begin{array}{c}\text { Total } \\
\text { Asset } \\
\text { (N'Billion } \\
\text { s) }\end{array}$ & $\begin{array}{c}\text { Shareholders } \\
\text { Fund (N'Billions) }\end{array}$ & $\begin{array}{l}\text { Total Deposit } \\
\text { (N'Billions) }\end{array}$ & $\begin{array}{l}\text { Loans to deposit } \\
\text { ratio in }(\%)\end{array}$ & $\begin{array}{l}\text { Liquidity ratio } \\
\text { in }(\%)\end{array}$ & \begin{tabular}{|l|} 
Total Credit \\
(N'Billions)
\end{tabular} & $\begin{array}{l}\text { Lending } \\
\text { Rate }(\%)\end{array}$ & $\begin{array}{c}\text { Cash Reserve } \\
\text { Ratio }(\%)\end{array}$ & $\begin{array}{c}\text { Gross Domestic } \\
\text { Product } \\
\text { (N'Billions) }\end{array}$ \\
\hline 2000 & 1568.0 & 7.9 & 702.1 & - & - & 508.3 & 17.98 & - & 6897.48 \\
\hline 2001 & 2247.0 & 15.9 & 947.2 & 65.6 & 52.9 & 796.2 & 18.29 & - & 8134.14 \\
\hline 2002 & 2766.9 & 35.4 & 1157.1 & 62.8 & 52.5 & 954.6 & 24.85 & - & 11332.25 \\
\hline 2003 & 3047.9 & 62.9 & 1337.3 & 61.9 & 50.9 & 1210.0 & 20.71 & - & 13301.56 \\
\hline 2004 & 3753.3 & 72.8 & 1661.5 & 68.6 & 50.5 & 1519.2 & 19.18 & - & 17321.30 \\
\hline 2005 & 4515.1 & 88.4 & 2036.1 & 70.8 & 50.2 & 1976.7 & 17.95 & - & 22269.98 \\
\hline 2006 & 7172.9 & 141.6 & 3245.2 & 63.6 & 55.7 & 2524.3 & 17.26 & - & 28662.47 \\
\hline 2007 & 10981.7 & 292.3 & 5001.5 & 70.8 & 48.8 & 4813.5 & 16.94 & - & 32995.38 \\
\hline 2008 & 15919.6 & 480.7 & 7960.1 & 80.9 & 44.3 & 7799.4 & 15.14 & 3.0 & 39157.88 \\
\hline 2009 & 17522.9 & 890.3 & 9150.0 & 85.7 & 30.7 & 8912.1 & 18.99 & 1.3 & 44285.56 \\
\hline 2010 & 17331.6 & 1869.1 & 9792.6 & 74.2 & 30.4 & 7706.4 & 17.59 & 1.0 & 54612.26 \\
\hline 2011 & 19396.6 & 2574.7 & 11452.8 & 44.8 & 42.0 & 7312.7 & 16.02 & 8.0 & 62980.40 \\
\hline 2012 & 21288.1 & 2551.2 & 13132.1 & 42.3 & 49.7 & 8150.0 & 16.79 & 12.0 & 71713.94 \\
\hline 2013 & 24301.2 & 1836.9 & 13767.4 & 38.0 & 63.2 & 10005.6 & 16.72 & 12.0 & 80092.56 \\
\hline 2014 & 27526.4 & 889.0 & 17185.8 & 64.2 & 38.3 & 12889.4 & 16.55 & 20.0 & 89043.62 \\
\hline 2015 & 28173.3 & 1223.2 & 17276.7 & 69.6 & 42.3 & 13222.65 & 16.85 & 20.0 & 94144.96 \\
\hline 2016 & 30836.78 & 1477.83 & 17930.25 & 75.95 & 41.25 & 15829.30 & 16.87 & 22.5 & 101498.49 \\
\hline 2017 & 33302.53 & 1537.90 & 18140.35 & 78.175 & 49.05 & 15775.45 & 17.58 & 22.5 & 113711.63 \\
\hline
\end{tabular}

Source: CBN Statistical Bulletin (December, 2017).

\subsection{Data Analysis}

\section{Credit Supply Equation 1}

Table 1. Model Summary b

\begin{tabular}{|c|c|c|c|c|c|c|c|c|c|c|}
\hline \multirow[b]{2}{*}{$\begin{array}{c}\text { Mode } \\
1\end{array}$} & \multirow[b]{2}{*}{$\mathrm{R}$} & \multirow[b]{2}{*}{$\begin{array}{c}\mathrm{R} \\
\text { Square }\end{array}$} & \multirow[b]{2}{*}{$\begin{array}{l}\text { Adjusted } \\
\text { R Square }\end{array}$} & \multirow[b]{2}{*}{$\begin{array}{l}\text { Std. Error of the } \\
\text { Estimate }\end{array}$} & \multicolumn{5}{|c|}{ Change Statistics } & \multirow[b]{2}{*}{ Durbin-Watson } \\
\hline & & & & & $\begin{array}{l}\text { R Square } \\
\text { Change }\end{array}$ & $\begin{array}{c}\mathrm{F} \\
\text { Change }\end{array}$ & df1 & df 2 & Sig. F Change & \\
\hline 1 & $\begin{array}{c}.496 \\
\mathrm{a}\end{array}$ & .246 & .199 & 4722.87058 & .246 & 5.227 & 1 & 16 & .036 & .467 \\
\hline
\end{tabular}

a. Predictors: (Constant), LRA

b. Dependent Variable: TC

Source: Compiled by authors. 
Financial Markets, Institutions and Risks, Volume 3, Issue 4, 2019

ISSN (online) - 2521-1242 ISSN (print) - 2521-1250

Table 2. ANOVAb

\begin{tabular}{|l|l|l|l|l|l|l|}
\hline Model & Sum of Squares & df & Mean Square & F \\
\hline \multirow{5}{*}{1} & Regression & $1.166 \mathrm{E} 8$ & 1 & $1.166 \mathrm{E} 8$ & 5.227 \\
\cline { 2 - 7 } & Residual & $3.569 \mathrm{E} 8$ & 16 & $2.231 \mathrm{E} 7$ & & \\
\cline { 2 - 7 } & Total & $4.735 \mathrm{E} 8$ & 17 & & & \\
\end{tabular}

a. Predictors: (Constant), LRA

b. Dependent Variable: TC

Source: Compiled by authors.

Table 2. Coefficientsa

\begin{tabular}{|c|c|c|c|c|c|c|c|c|c|c|c|c|}
\hline \multirow[b]{2}{*}{ Model } & \multicolumn{2}{|c|}{$\begin{array}{c}\text { Unstandardized } \\
\text { Coefficients }\end{array}$} & \multirow{2}{*}{$\begin{array}{c}\begin{array}{c}\text { Standar } \\
\text { dized } \\
\text { Coeffici } \\
\text { ents }\end{array} \\
\text { Beta }\end{array}$} & \multirow[b]{2}{*}{$\mathrm{t}$} & \multirow[b]{2}{*}{ Sig. } & \multicolumn{2}{|c|}{$\begin{array}{c}95 \% \text { Confidence Interval for } \\
\text { B }\end{array}$} & \multicolumn{3}{|c|}{ Correlations } & \multicolumn{2}{|c|}{ Collinearity Statistics } \\
\hline & B & Std. Error & & & & Lower Bound & $\begin{array}{l}\text { Upper } \\
\text { Bound }\end{array}$ & Zero-order & Partial & Part & Tolerance & VIF \\
\hline \begin{tabular}{|l|l|}
1 & (Constant) \\
\end{tabular} & 28593.956 & 9609.477 & & 2.976 & .009 & 8222.775 & 48965.137 & & & & & \\
\hline LRA & -1218.846 & 533.129 & -.496 & -2.286 & .036 & -2349.029 & -88.664 & -.496 & -.496 & -.496 & 1.000 & 1.000 \\
\hline
\end{tabular}

a. Dependent Variable: TC

Source: Compiled by authors.

Table 3. Collinearity Diagnosticsa

\begin{tabular}{|c|c|c|c|c|c|}
\hline \multirow{2}{*}{ Model } & & & & \multicolumn{2}{|c|}{ Variance Proportions } \\
\cline { 3 - 6 } & Dimension & Eigenvalue & Condition Index & LRA \\
\cline { 2 - 6 } & 1 & 1.993 & 1.000 & .00 & 1.00 \\
\hline
\end{tabular}

a. Dependent Variable: TC

Source: Compiled by authors.

Table 4. Credit Supply Equation II

\begin{tabular}{|c|c|c|c|c|c|c|c|c|c|c|}
\hline \multicolumn{11}{|c|}{ Model Summaryb } \\
\hline \multirow[b]{2}{*}{ Model } & \multirow[b]{2}{*}{$\mathrm{R}$} & \multirow[b]{2}{*}{ R Square } & \multirow{2}{*}{$\begin{array}{l}\text { Adjusted } \mathrm{R} \\
\text { Square }\end{array}$} & \multirow{2}{*}{$\begin{array}{l}\text { Std. Error of the } \\
\text { Estimate }\end{array}$} & \multicolumn{5}{|l|}{ Change Statistics } & \multirow{2}{*}{\begin{tabular}{|l|} 
Durbin- \\
Watson
\end{tabular}} \\
\hline & & & & & R Square Change & F Change & df1 & $d f 2$ & Sig. F Change & \\
\hline 1 & $.907 a$ & .823 & .812 & 2286.97561 & .823 & 74.526 & 1 & 16 & .000 & .470 \\
\hline
\end{tabular}

a. Predictors: (Constant), CRR

b. Dependent Variable: TC

Source: Compiled by authors.

Table 5. ANOVAb

\begin{tabular}{|c|c|c|c|c|c|c|}
\hline \multicolumn{7}{|c|}{ ANOVAb } \\
\hline \multicolumn{2}{|c|}{ Model } & Sum of Squares & df & Mean Square & $\mathrm{F}$ & Sig. \\
\hline \multirow[t]{3}{*}{1} & Regression & $3.898 \mathrm{E} 8$ & 1 & $3.898 \mathrm{E} 8$ & 74.526 & $.000 \mathrm{a}$ \\
\hline & Residual & $8.368 \mathrm{E} 7$ & 16 & 5230257.432 & & \\
\hline & Total & $4.735 \mathrm{E} 8$ & 17 & & & \\
\hline
\end{tabular}

a. Predictors: (Constant), CRR

b. Dependent Variable: TC

Source: Compiled by authors.

Table 6. Coefficientsa

\begin{tabular}{|c|c|c|c|c|c|c|c|c|c|c|c|c|}
\hline \multicolumn{13}{|l|}{ Coefficientsa } \\
\hline \multirow[b]{2}{*}{ Model } & \multicolumn{2}{|c|}{$\begin{array}{l}\text { Unstandardized } \\
\text { Coefficients }\end{array}$} & \multirow{2}{*}{\begin{tabular}{|l}
$\begin{array}{l}\text { Standardized } \\
\text { Coefficients }\end{array}$ \\
Beta \\
\end{tabular}} & \multirow[b]{2}{*}{$\mathrm{t}$} & \multirow[b]{2}{*}{ Sig. } & \multicolumn{2}{|c|}{$95 \%$ Confidence Interval for B } & \multicolumn{3}{|c|}{ Correlations } & \multicolumn{2}{|c|}{$\begin{array}{l}\text { Collinearity } \\
\text { Statistics }\end{array}$} \\
\hline & B & Std. Error & & & & Lower Bound & Upper Bound & $\begin{array}{l}\text { Zero- } \\
\text { order }\end{array}$ & Partial & Part & $\begin{array}{l}\text { Toleranc } \\
\mathrm{e}\end{array}$ & VIF \\
\hline \begin{tabular}{|l|l|}
1 & (Constant) \\
\end{tabular} & 3115.157 & 685.607 & & 4.544 & .000 & 1661.734 & 4568.579 & & & & & \\
\hline CRR & 538.291 & 62.354 & .907 & 8.633 & .000 & 406.107 & 670.475 & .907 & .907 & .907 & 1.000 & 1.000 \\
\hline
\end{tabular}

a. Dependent Variable: TC

Source: Compiled by authors.

Table 7. Collinearity Diagnosticsa

\begin{tabular}{|c|c|c|c|c|c|}
\hline \multirow{3}{*}{ Model } & & & & \multicolumn{2}{|c|}{ Variance Proportions } \\
\cline { 3 - 6 } & Dimension & Eigenvalue & Condition Index & CRR \\
\cline { 2 - 6 } & 1 & 1.618 & 1.000 & .19 & .19 \\
\hline
\end{tabular}

a. Dependent Variable: TC.

Source: Compiled by authors.

Table 8. Commercial Bank performance equation III

\begin{tabular}{|c|c|c|c|c|c|c|c|c|c|c|}
\hline \multicolumn{11}{|c|}{ Model Summaryb } \\
\hline \multirow[b]{2}{*}{ Model } & \multirow[b]{2}{*}{$\mathrm{R}$} & \multirow[b]{2}{*}{ R Square } & \multirow[b]{2}{*}{ Adjusted R Square } & \multirow[b]{2}{*}{$\begin{array}{l}\text { Std. Error of the } \\
\text { Estimate }\end{array}$} & \multicolumn{5}{|l|}{ Change Statistics } & \multirow[b]{2}{*}{ Durbin-Watson } \\
\hline & & & & & $\begin{array}{l}\mathrm{R} \quad \text { Square } \\
\text { Change }\end{array}$ & F Change & df1 & df2 & Sig. F Change & \\
\hline 1 & $.995 \mathrm{a}$ & .989 & .988 & 1200.27644 & .989 & 694.781 & 2 & 15 & .000 & 1.008 \\
\hline
\end{tabular}

a. Predictors: (Constant), SHF, TD

b. Dependent Variable: TAS 
Table 9. ANOVAb

\begin{tabular}{|c|c|c|c|c|c|c|}
\hline \multicolumn{7}{|c|}{ ANOVAb } \\
\hline \multicolumn{2}{|c|}{ Model } & Sum of Squares & $\mathrm{df}$ & Mean Square & $\mathrm{F}$ & Sig. \\
\hline \multirow[t]{3}{*}{1} & Regression & $2.002 \mathrm{E} 9$ & 2 & $1.001 \mathrm{E} 9$ & 694.781 & $.000 \mathrm{a}$ \\
\hline & Residual & $2.161 \mathrm{E} 7$ & 15 & 1440663.531 & & \\
\hline & Total & $2.024 \mathrm{E} 9$ & 17 & & & \\
\hline
\end{tabular}

a. Predictors: (Constant), SHF, TD

b. Dependent Variable: TAS

Source: Compiled by authors.

Table 10. Coefficientsa

\begin{tabular}{|c|c|c|c|c|c|c|c|c|c|c|c|c|c|}
\hline \multirow{2}{*}{\multicolumn{2}{|c|}{ Model }} & \multicolumn{2}{|c|}{$\begin{array}{l}\text { Unstandardized } \\
\text { Coefficients }\end{array}$} & \multirow{2}{*}{\begin{tabular}{|l|}
$\begin{array}{l}\text { Standardized } \\
\text { Coefficients }\end{array}$ \\
Beta \\
\end{tabular}} & \multirow[b]{2}{*}{$\mathrm{t}$} & \multirow[b]{2}{*}{ Sig. } & \multicolumn{2}{|c|}{$\begin{array}{l}95 \% \text { Confidence Interval } \\
\text { for B }\end{array}$} & \multicolumn{3}{|c|}{ Correlations } & \multicolumn{2}{|c|}{$\begin{array}{l}\text { Collinearity } \\
\text { Statistics }\end{array}$} \\
\hline & & B & Std. Error & & & & $\begin{array}{l}\text { Lower } \\
\text { Bound }\end{array}$ & Upper Bound & $\begin{array}{l}\begin{array}{l}\text { Zero- } \\
\text { order }\end{array} \\
\end{array}$ & Partial & Part & $\begin{array}{l}\text { Toleranc } \\
\mathrm{e}\end{array}$ & VIF \\
\hline \multirow[t]{3}{*}{1} & (Constant) & 1280.297 & 466.595 & & 2.744 & .015 & 285.774 & 2274.821 & & & & & \\
\hline & TD & 1.668 & .067 & 1.013 & 24.864 & .000 & 1.525 & 1.811 & .995 & .988 & .663 & .429 & 2.330 \\
\hline & SHF & -.291 & .495 & -.024 & -.588 & .565 & -1.347 & .764 & .741 & -.150 & -.016 & .429 & 2.330 \\
\hline
\end{tabular}

a. Dependent Variable: TAS.

Source: Compiled by authors.

Table 11. Collinearity Diagnosticsa

\begin{tabular}{|c|c|c|c|c|c|c|}
\hline \multicolumn{7}{|c|}{ Collinearity Diagnosticsa } \\
\hline \multirow[b]{2}{*}{ Model } & \multirow[b]{2}{*}{ Dimension } & \multirow[b]{2}{*}{ Eigenvalue } & \multirow[b]{2}{*}{ Condition Index } & \multicolumn{3}{|c|}{ Variance Proportions } \\
\hline & & & & (Constant) & TD & SHF \\
\hline \multirow[t]{3}{*}{1} & 1 & 2.601 & 1.000 & .04 & .02 & .03 \\
\hline & 2 & .300 & 2.946 & .80 & .02 & .21 \\
\hline & 3 & .099 & 5.124 & .16 & .95 & .76 \\
\hline
\end{tabular}

a. Dependent Variable: TAS

Source: Compiled by authors.

Table 12. Commercial Bank performance equation IV

\begin{tabular}{|c|c|c|c|c|c|c|c|c|c|c|}
\hline \multicolumn{11}{|c|}{ Model Summaryb } \\
\hline \multirow[b]{2}{*}{ Model } & \multirow[b]{2}{*}{$\mathrm{R}$} & \multirow[b]{2}{*}{ R Square } & \multirow[b]{2}{*}{$\begin{array}{ll}\text { Adjusted } & \mathrm{R} \\
\text { Square } & \end{array}$} & \multirow[b]{2}{*}{$\begin{array}{l}\text { Std. Error of } \\
\text { the Estimate }\end{array}$} & \multicolumn{5}{|l|}{ Change Statistics } & \multirow[b]{2}{*}{$\begin{array}{l}\text { Durbin- } \\
\text { Watson }\end{array}$} \\
\hline & & & & & $\begin{array}{l}\mathrm{R} \text { Square } \\
\text { Change }\end{array}$ & F Change & df1 & df2 & Sig. F Change & \\
\hline 1 & $.409 a$ & .168 & .116 & 18.95238 & .168 & 3.223 & 1 & 16 & .092 & .903 \\
\hline
\end{tabular}

a. Predictors: (Constant), LR

b. Dependent Variable: LDR.

Source: Compiled by authors

Table 13. Coefficientsa

\begin{tabular}{|c|c|c|c|c|c|c|c|c|c|c|c|c|c|}
\hline \multirow{2}{*}{\multicolumn{2}{|c|}{ Model }} & \multicolumn{2}{|c|}{$\begin{array}{l}\text { Unstandardized } \\
\text { Coefficients }\end{array}$} & \multirow{2}{*}{$\begin{array}{c}\begin{array}{c}\text { Standardized } \\
\text { Coefficients }\end{array} \\
\text { Beta } \\
\end{array}$} & \multirow[b]{2}{*}{$\mathrm{T}$} & \multirow[b]{2}{*}{ Sig. } & \multicolumn{2}{|c|}{$\begin{array}{c}95 \% \text { Confidence } \\
\text { Interval for B }\end{array}$} & \multicolumn{3}{|c|}{ Correlations } & \multicolumn{2}{|c|}{$\begin{array}{c}\text { Collinearity } \\
\text { Statistics }\end{array}$} \\
\hline & & B & $\begin{array}{l}\text { Std. } \\
\text { Error }\end{array}$ & & & & $\begin{array}{l}\text { Lower } \\
\text { Bound }\end{array}$ & $\begin{array}{l}\text { Upper } \\
\text { Bound }\end{array}$ & $\begin{array}{l}\text { Zero- } \\
\text { order }\end{array}$ & Partial & Part & $\begin{array}{c}\text { Toleranc } \\
\mathrm{e}\end{array}$ & VIF \\
\hline \multirow[t]{2}{*}{1} & (Constant) & 35.663 & 15.391 & & 2.317 & .034 & 3.035 & 68.291 & & & & & \\
\hline & LR & .600 & .334 & .409 & 1.795 & .092 & -.109 & 1.309 & .409 & .409 & .409 & 1.000 & 1.000 \\
\hline
\end{tabular}

a. Dependent Variable: LDR.

Source: Compiled by authors.

Table 14. Collinearity Diagnosticsa

\begin{tabular}{|c|c|c|c|c|c|}
\hline \multirow{3}{*}{ Model } & & & & \multicolumn{2}{|c|}{ Variance Proportions } \\
\cline { 3 - 6 } & Dimension & Eigenvalue & Condition Index & LR \\
\cline { 2 - 6 } & 1 & 1.957 & 1.000 & .02 & .02 \\
\hline
\end{tabular}

a. Dependent Variable: LDR.

Source: Compiled by authors.

Table 15. Commercial Bank performance equation $\mathrm{V}$

\begin{tabular}{|c|c|c|c|c|c|c|c|c|c|c|}
\hline \multicolumn{11}{|c|}{ Model Summaryb } \\
\hline \multirow[b]{2}{*}{ Model } & \multirow[b]{2}{*}{$\mathrm{R}$} & \multirow[b]{2}{*}{ R Square } & \multirow[b]{2}{*}{$\begin{array}{c}\text { Adjusted R } \\
\text { Square }\end{array}$} & \multirow[b]{2}{*}{$\begin{array}{l}\text { Std. Error of } \\
\text { the Estimate }\end{array}$} & \multicolumn{5}{|c|}{ Change Statistics } & \multirow[b]{2}{*}{$\begin{array}{l}\text { Durbin- } \\
\text { Watson }\end{array}$} \\
\hline & & & & & $\begin{array}{l}\text { R Square } \\
\text { Change }\end{array}$ & F Change & df1 & df2 & Sig. F Change & \\
\hline 1 & $.971 \mathrm{a}$ & .943 & .939 & 8655.60837 & .943 & 263.392 & 1 & 16 & .000 & .941 \\
\hline
\end{tabular}

a. Predictors: (Constant), TC.

b. Dependent Variable: GDP.

Source: Compiled by authors. 
Table 16. ANOVAb

\begin{tabular}{|c|c|c|c|c|c|c|}
\hline \multicolumn{2}{|c|}{ Model } & Sum of Squares & df & Mean Square & F \\
\hline \multirow{3}{*}{1} & Regression & $1.973 \mathrm{E} 10$ & 1 & $1.973 \mathrm{E} 10$ & 263.392 & $.000 \mathrm{a}$ \\
\cline { 2 - 7 } & Residual & $1.199 \mathrm{E} 9$ & 16 & $7.492 \mathrm{E} 7$ & & \\
\cline { 2 - 7 } & Total & $2.093 \mathrm{E} 10$ & 17 & & & \\
\hline
\end{tabular}

a. Predictors: (Constant), TC

b. Dependent Variable: GDP

Source: Compiled by authors.

Table 17. Coefficientsa

\begin{tabular}{|c|c|c|c|c|c|c|c|c|c|c|c|c|c|}
\hline & & \multicolumn{2}{|c|}{$\begin{array}{l}\text { Unstandardized } \\
\text { Coefficients }\end{array}$} & \multirow{2}{*}{\begin{tabular}{|l}
$\begin{array}{l}\text { Standardized } \\
\text { Coefficients }\end{array}$ \\
Beta \\
\end{tabular}} & \multirow[b]{2}{*}{$\mathrm{T}$} & \multirow[b]{2}{*}{ Sig. } & \multicolumn{2}{|c|}{$\begin{array}{l}95 \% \text { Confidence } \\
\text { Interval for B }\end{array}$} & \multicolumn{3}{|c|}{ Correlations } & \multicolumn{2}{|c|}{$\begin{array}{l}\text { Collinearity } \\
\text { Statistics } \\
\end{array}$} \\
\hline \multicolumn{2}{|c|}{ Model } & B & Std. Error & & & & $\begin{array}{l}\text { Lower } \\
\text { Bound }\end{array}$ & $\begin{array}{l}\text { Upper } \\
\text { Bound }\end{array}$ & $\begin{array}{l}\text { Zero- } \\
\text { order }\end{array}$ & Partial & Part & $\begin{array}{l}\text { Toleranc } \\
\text { e }\end{array}$ & VIF \\
\hline \multirow[t]{2}{*}{1} & (Constant) & 5841.967 & 3379.343 & & 1.729 & .103 & -1321.921 & 13005.855 & & & & & \\
\hline & $\mathrm{TC}$ & 6.456 & .398 & .971 & 16.229 & .000 & 5.613 & 7.299 & .971 & .971 & .971 & 1.000 & 1.000 \\
\hline
\end{tabular}

a. Dependent Variable: GDP

Source: Compiled by authors.

Table 18. Collinearity Diagnosticsa

\begin{tabular}{|c|c|c|c|c|c|}
\hline \multirow{3}{*}{ Model } & & & & \multicolumn{2}{|c|}{ Variance Proportions } \\
\cline { 3 - 6 } & Dimension & Eigenvalue & Condition Index & TC \\
\cline { 2 - 6 } & 1 & 1.797 & 1.000 & .10 & .90 \\
\hline
\end{tabular}

a. Dependent Variable: GDP

Source: Compiled by authors.

\subsection{Summary of Findings}

(1) There was a weak correlation between the dependent variable (Total Credit) and independent variable (Lending Rate) in the credit supply equation I. This means that commercial banks' lending rate reduce the volume of credit to commercial bank customers. This is because many bank customers/investors consider other sources of finance to their businesses because of high lending rate of commercial banks. The coefficient of determination of $24.6 \%$ in credit supply equation I measures the strength of the relationship or cause effect relationship which means that $24.6 \%$ variation in the dependent variable (Total Credit) is explained by the independent variable (Lending Rate) and $75.4 \%$ of the variation in the dependent variable is explained by the disturbance term or error term due to inflationary pressure, economic meltdown, low profitability, nonperforming loans etc. Besides, in credit supply equation I, Lending rate has been found as a decreasing function of Total Credit, this increase the value of the Total loans. This means that lending rate have negative effect on Total Credit. The parameter of Total Creditin relationship with lending rate wasstatistically significant at 5\%, this means that high lending rate hinders the adequate performance of Commercial Banks financial intermediation simply because of high lending rate which does not attract many commercial banks customers/investors and reduces investor's profit margin. The reverse is the case if there is low interest rate in commercial banks.

(2) There exist a positive or strong correlation between the dependent variable (Total Credit) and independent variable (Cash reserve ratio) in the credit supply equation 2. This means that with the level of minimum reserve kept by commercial banks with central bank of Nigeria, adequate credit to commercial banks customers is guaranteed, though, lending rate may hinder many customers/investors to consider other sources of finance but with the minimum reserve, sufficient credit is guaranteed for commercial banks customers/investors. The coefficient of determination of $82.3 \%$ in credit supply equation 2 measures the strength of the relationship or cause effect relationship which means that $82.3 \%$ variation in the dependent variable (Total Credit) was explained by the independent variable (Cash reserve ratio) and $17.7 \%$ of the variation in the dependent variable was explained by the disturbance term or error term due to inflationary pressure, economic meltdown, low profitability, non-performing loans etc. Besides, in MFBs Performance equation 2, independent variables have been found as an increasing function of dependent variable, this increase the value of the Total Credit. This means that Cash reserve ratio have positive effect on Total Credit. The parameter of Total Credit in relationship with Cash reserve ratio was statistically significant at 5\%. This means that the variables are not equal to zero. Also, this means that minimum reserve maintained with the CBN by commercial banks strengthen the ability of commercial banks to perform their financial intermediation role.

(3) There exist a positive or strong correlation between the dependent variable (Total Asset) and independent variables (Total Deposit and Shareholders Fund) in the commercial bank Performance equation 3. This means 
Financial Markets, Institutions and Risks, Volume 3, Issue 4, 2019

ISSN (online) - 2521-1242 ISSN (print) - 2521-1250

that the Capital employed by commercial banks have positive effect on Total Asset of commercial banks in Nigeria.The coefficient of determination of $98.9 \%$ in commercial bank Performance equation 3 measures the strength of the relationship or cause effect relationship which means that $98.9 \%$ variation in the dependent variable (Total Asset) was well explained by the independent variable (Total Deposit and Shareholders Fund) and $1.1 \%$ of the variation in the dependent variable was explained by the disturbance term or error term due to inflationary pressure, economic meltdown, low profitability, non-performing loans etc. Besides, in commercial bank Performance equation 3, independent variables have been found as an increasing function of dependent variable, this increase the value of the Total Asset. This means that total deposit and shareholders' funds (Capital employed) have an increasing function on Total Asset. The parameter of Total Asset in relationship with Total Deposit and Shareholders Fund was statistically significant at 5\%. This means that the variables are not equal to zero. Also, this means that efficient utilization of Total deposit and Shareholders fund in form of loan distribution and meeting up with deposit demands leads to an increase in total asset of commercial banks.

(4) There exists a weak correlation between the dependent variable (Loans to deposit ratio) and independent variable (Liquidity ratio) in the commercial bank performance equation 4. This means that majority of Commercial Banks in Nigeria do not have absolute ability to meet up with their day to day short and long term obligations. The coefficient of determination of $16.8 \%$ in commercial bank performance equation 4 measures the strength of the relationship or cause effect relationship which means that $16.8 \%$ variation in the dependent variable (loan to deposit ratio) was explained by the independent variable (Liquidity ratio) and $83.2 \%$ of the variation in the dependent variable was explained by the disturbance term or error term due to inflationary pressure, economic meltdown, low profitability, non-performing loans etc. Besides, in commercial bank performance equation 4, Liquidity ratio has been found as a decreasing function of loans to deposit ratio, this decrease the value of the loans to deposit ratio. This means that Liquidity is low and because of this it has negative effect on loans to deposit ratio. The parameter of Loans to deposit ratio in relationship with Liquidity ratio was not statistically significant at 5\%. Also, this means that Commercial Banks in Nigeria do not have the absolute ability to meet up with their day to day short- and long-term obligations which is a factor that hinders an adequate financial intermediation in Commercial Banks.

(5) There exist a positive or strong correlation between the dependent variable (Gross Domestic Product) and independent variable (Total Credit) in the Commercial bank performance equation 5. This means that Bank Credit/loan is still greatly increasing the production of goods and services in the Nigeria Commercial Banking System because of utilisation of the loans by investors. The coefficient of determination of $94.5 \%$ in Commercial bank performance equation 5measures the strength of the relationship or cause effect relationship which means that $94.5 \%$ variation in the dependent variable (Gross Domestic Product) was well explained by the independent variable (Total Credit) and 5.5\% of the variation in the dependent variable was explained by the disturbance term or error term due to inflationary pressure, economic meltdown, low profitability, nonperforming loans etc. Besides, in Commercial bank Performance equation 5, independent variables have been found as an increasing function of dependent variable, this increase the value of the Gross Domestic Product. This means that giving loan and advances to Commercial Banks Customers/Investor have positive effect on Gross Domestic Product because of the usage of the loans for productive purpose by the investors. The parameter of Gross Domestic Product in relationship with Total Credit was statistically significant at 5\%. This means that the variables are not equal to zero. Also, this means that deficit sector is highly encouraged to produce more through Bank Credit/loan, and this have positive effect on GDP.

\section{Conclusion}

It is evident from the results of the study that the commercial banks reform strategies adopted in Nigeria have been geared towards making credit available to support the economy. As a result of this, supply of credit to the real sector has been improved. The conclusions that can be drawn from the findings of this study is that with the level of minimum reserve maintained by commercial bank with Central bank of Nigeria, there is adequate availability of credit for real sector investments. The returns on asset of Commercial bank experienced an improvement level within the period of analysis. High lending rates of commercial banks make many customers/investors to consider other source of finance and vice versa. Bank Credit/loan is still greatly increasing the production of goods and services in the Nigeria Commercial Banking System because of utilisation of the loans by investors. 


\section{Recommendations}

Base on the objective and findings of this study, the study therefore recommends that:

Commercial banks' lending rate should be reduced in order for investors to see commercial banks as number one source of finance.

$>\quad$ Central Bank of Nigeria should increase the minimum reserve of Commercial banks in order to facilitate an adequate credit to commercial banks customers/ investors.

Commercial banks should effectively utilize capital employed in order to increase the profitability level of commercial banks which will increase the total asset of commercial banks.

Commercial banks should foster higher level of liquidity in order to increase its ability to cover withdrawals made by its customers and to increase the loan and advances to customers.

$>$ Commercial banks should distribute adequate credit to the real sector for productive purposes in order to increase Gross domestic product.

\section{References}

1. Adeoye T. (2003). Determinant of Credit Flow from the Nigerian Banking System; An Empirical Analysis, Niser Monograph Series No 6 Nigeria Institute of Social and Economic Research (NISER), Ibadan.

2. Acha, I.A. (2011). Does Bank Financial Intermediation Cause Economic Growth in Developing Economies: The Nigerian Experience. International Business and Management, 3(1), 156-161.

3. Andrew, O.A. \& Osuji, C. C. (2013). An Empirical Analysis of Trends in Financial Intermediation and Output in Nigeria. Global Journals Inc. (USA), 13(9), 210-216.

4. Blum, J. (2000). Do capital adequacy requirements reduce risk in banking? Journal of banking and finance 23:755-71.

5. Gorton, G., \& Winton, A. (2002). Financial intermediation. National Bureau of Economic Research Working Paper 8928. Retrieved from: http://www.nber.org/papers/w8928.

6. Mahmood, H. and Bilal, K. (2010). What drives interest Rate Spreads of Commercial banks in Pakistan? Empirical Evidence Based on Panel Data. BSP Research Bulletin, 6(2), 15-36.

7. Olukotun G.A. Adewole J.A\& James S.O. (2015). Bank Consolidation and the Efficiency of Financial Intermediation in the Nigerian Banking system'. Journal of Leadership, Accounting Development and Investigation (JLADIR), Kogi State University. 2,1. Nigeria.

8. Onodugo, V., Kalu, I. E., \& Anowor, O. F. (2013). Financial intermediation and private sector investment in Nigeria. Research Journal of Finance and Accounting, 4(12) 162-173.

9. Tonye, O. and Andabai, P. (2014). Financial Intermediation and Economic Growth in Nigeria. Mediterrnean Journal of Social Sciences, 5(7), 12-25.

10. Wuryandani G. (2011) Banking Intermediation to Promote Real Sector Development in Indonesia International Review of Business Research Papers 7, 1. January 2011, 211 - 230. 